Brazilian Journal

of Chemical

ISSN 0104-6632

Engineering

Vol. 34, No. 04, pp. 961 - 969, October - December, 2017

dx.doi.org/10.1590/0104-6632.20170344s2016050

Printed in Brazil

www.scielo.br/bjce

$(\mathrm{cc}) \overline{\mathrm{EY}}$

\title{
NUTRIENT BIOLOGICAL REMOVAL IN AN UP-FLOW SLUDGE BED REACTOR UNDER INTERMITTENT AERATION USING GLYCEROL AS THE SOLE CARBON SOURCE
}

\author{
R. B. Carneiro ${ }^{1, *}$ and E. Foresti ${ }^{1}$ \\ ${ }^{1,}$ Laboratory of Biological Processes, Center for Research, Development and Innovation in Environmental Engineering, \\ São Carlos School of Engineering, Universidade de São Paulo, Avenida João Dagnone, 1100, Santa Angelina, 13563-120, \\ São Carlos, São Paulo, Brazil. E-mail: foresti@sc.usp.br \\ *Corresponding author: E-mail rodrigobrazcarneiro@yahoo.com.br
}

(Submitted: May 30, 2016; Revised: July 12, 2016; Accepted: July 15, 2016)

\begin{abstract}
This work evaluated the feasibility of glycerol as the sole carbon source for nutrient biological removal in an intermittently aerated bioreactor. The reactor operation was divided into two phases: the first one aimed only at removing nitrogen; and the second one aimed at removing nitrogen and phosphorus. In the first operational phase, three $\mathrm{C} / \mathrm{N}$ (Carbon / Nitrogen) ratios were tested: 1.2, 1.5 and 1.8. For a $\mathrm{C} / \mathrm{N}$ ratio of 1.8 , higher denitrification efficiency was achieved $(91 \pm 8 \%)$. During the second phase, the reactor was subjected to periods of aeration and non-aeration of $2 \mathrm{~h}$ and $4 \mathrm{~h}$, respectively, for a C/P (Carbon / Phosphorus) ratio of 10. The biological phosphorus removal in this phase was not significant $(12 \pm 9 \%$ ), indicating that there was no development of PAO (Phosphorus Accumulating Organisms), since phosphate release did not occur during the anaerobic phase. This can be explained by the lack of VFA (Volatile Fatty Acids), which should come from the anaerobic degradation of the remaining amount of glycerol after denitrification was completed. The optical microscopy analysis indicated the presence of filamentous bacteria similar to the genus Beggiatoa, which could also have consumed part of the substrates from the glycerol fermentation.
\end{abstract}

Keywords: Denitrification, Biological Phosphorus Removal, Glycerol, C/N ratio, intermittent aeration.

\section{INTRODUCTION}

Due to problems arising from sewage emissionsin water bodies with high concentrations of nitrogen and phosphorus, especially artificial eutrophication, treatment technologies to remove these compounds have been sought. These nutrients are not removed in conventional biological processes, such as anaerobic bioreactors and conventional activated sludge, and therefore they require post-treatment or adequacy of current systems.

Complete nitrogen removal in conventional biological systems generally requires the addition of an external carbon source in the denitrification step in order to promote the nitrate reduction to nitrite and then finally to nitrogen gas.

For biological phosphorus removal (BPR), an anaerobic zone followed by an aerobic zone is needed in order to promote the development of phosphorus accumulating organisms (PAO). In the anaerobic step, PAO store the VFA (mainly acetic acid), resulting from the soluble organic matter fermentation, as poly- $\beta$-hydroxyalkanoates (PHA) and release phosphate. Under aerobic conditions, PAO accumulate this excess amount of phosphate intracellularly as polyphosphate (Poly-P). Then, the BPR is accomplished by the excess sludge discharge (Zeng et al., 2004).

\footnotetext{
* To whom correspondence should be addressed
} 
Thus, in nutrient biological removal systems, the soluble COD is a limiting factor for heterotrophic denitrification and phosphorus release in the anaerobic zone with subsequent incorporation into the aerobic biomass (Tam et al, 1992; Isaacs and Henze, 1995; Ahmed et al, 2008; Wang et al., 2009).Therefore, complete removal of nitrogen and phosphorus by a biological pathway usually requires additional costs by using an external carbon source, as a large part of the organic matter was already consumed in the previous biological unit, such as UASB or activated sludge.

Studies have been carried out in order to evaluate carbon sources that have a low cost and high availability to promote biological nutrient removal. Considering this, glycerol has shown to be a promising source, especially in Brazil, as a by-product of biodiesel production and to present a relatively low cost compared to other carbon sources, such as ethanol or acetic acid.

In 2014, glycerin generation in Brazil by the transesterification process was 311.8 thousand $\mathrm{m}^{3}$ (ANP, 2015), equivalent to approximately $10 \%$ of the total volume of produced biodiesel. In the country, it is mandatory to use $7 \%$ of biodiesel in regular diesel oil (B7), whereas production in 2014 reached only $45.6 \%$ of the total production capacity. In this scenario, glycerol shows a tendency to increase availability without a direct trading market for consuming the surplus production.

Generally, in conventional biological systems with complete removal of nitrogen and phosphorus various sequential units are necessary. Some studies (Santos et al., 2016; Wosiack et al., 2015; Barana et al., 2013; Moura et al., 2012; Asadi et al., 2012) have shown that the application of intermittent aeration in continuous flow reactors can satisfactorily remove nitrogen and organic matter in a single bioreaction zone, significantly reducing the cost of treatment. These studies did not assess or did not have significant phosphorus removal due to the lack of a carbon source available to promote orthophosphate release in the non-aerated phase and promote the development of $\mathrm{PAO}$ and also the presence of NOx (nitrite and nitrate) that favors the denitrifying bacteria in the system.

This work aimed at evaluating the use of glycerol as an electron donor for denitrification and biological phosphorus removal in a continuous up-flow sludge bed reactor undergoing intermittent aeration.

\section{MATERIALS AND METHODS}

\section{System configuration and operation}

The experimental apparatus consisted of a continuous up-flow bioreactor made of acrylic with an internal diameter of $8.1 \mathrm{~cm}$, a height of $74 \mathrm{~cm}$, and a working total volume of $3.45 \mathrm{~L}$ (Fig. 1). The reactor feed consisted of two separate streams, one containing a carbon source (Glycerol

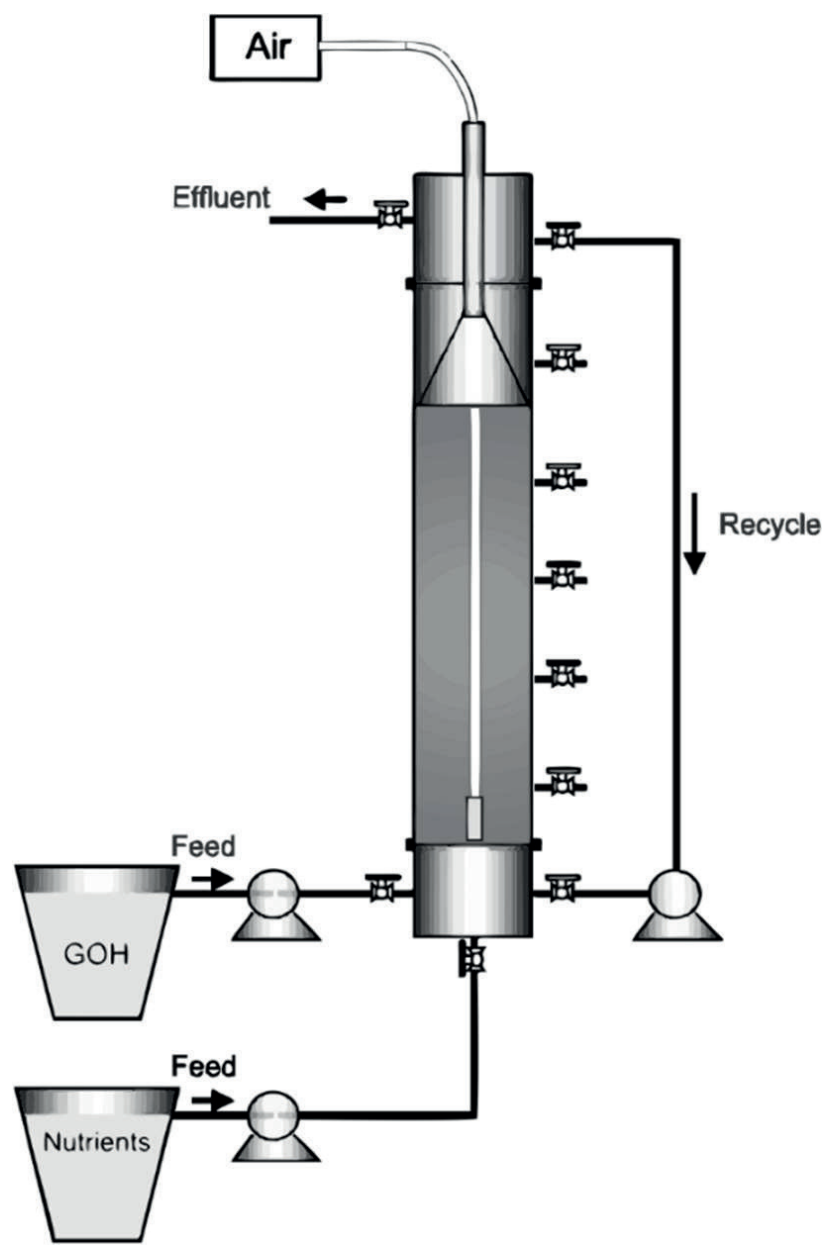

Figure 1. Schematic representation of the Up-flow Sludge Bed Reactor under Intermittent Aeration.

p.a.- $\mathrm{GOH}$ ) and another containing the nutrient solution in order to avoid partial denitrification prior to the bioreaction zone. Feeding and effluent recirculation were conducted by ProMinent Contact diaphragm pumps.

The aeration was supplied by an aerator Big Air Super Pump (Model A-420) linked to a porous stone, used for air diffusion in the liquid bulk. The aerator was adjusted to maintain the OD level at $2.5 \pm 0.5 \mathrm{mg} . \mathrm{L}^{-1}$. In the aeration tests, the OD reached this range in about 30 minutes. In the anoxic phase, the OD value was maintained below 0.3 mg. $L^{-1}$ after 5 minutes of aeration interruption.

The reactor start-up was achieved using the biological inoculum sludge collected from the Volkswagen wastewater treatment plant, located in São Carlos, São Paulo, Brazil. This inoculum is from a nitrification tank and therefore it has well developed nitrifying biomass, with VSS content of $4300 \mathrm{mg} \cdot \mathrm{L}^{-1}$. Acclimatization under anoxic conditions was performed to develop heterotrophic denitrifying biomass in order to start the operation of the treatment system. For this, Ethanol was used as electron donor at a high $\mathrm{C} / \mathrm{N}$ ratio $(2.6 \pm 0.5)$ for process acceleration. The reactor received $1.7 \mathrm{~L}$ of sludge, corresponding to $50 \%$ of the working volume. 
The reactor operation was divided into two main distinct phases. The first phase aimed to promote heterotrophic denitrification using glycerol as the sole carbon source. This phase was further subdivided into three sub-stages, increasing the $\mathrm{C} / \mathrm{N}$ ratio progressively, as shown in Table 1 . The second phase involved submitting the reactor to intermittent aeration creating two stages - aeration (2 h) and non-aeration stage $(4 \mathrm{~h})-$ in order to promote denitrification and biological phosphorus removal in the same reactor, using glycerol as electron donor during the non-aeration stage.

The temperature ranged between $23.0 \pm 1.4$ (minimum) and 26.4 \pm 2.0 (maximum), throughout the reactor operation.

Table 1. Working conditions in each operational reactor phase

\begin{tabular}{lcccc}
\hline & Phase 1a & Phase 1b & Phase 1c & Phase 2 \\
\hline COD/N & $3.4 \pm 0.6$ & $4.1 \pm 0.1$ & $5.1 \pm 0.2$ & $9.9 \pm 0.8$ \\
C/N & $1.2 \pm 0.1$ & $1.5 \pm 0.1$ & $1.8 \pm 0.2$ & $3.5 \pm 0.2$ \\
COD/P & - & - & - & $29.0 \pm 3.5$ \\
C/P & - & - & - & $10.2 \pm 1.0$ \\
HRT (h) & 4 & 4 & 4 & 10 \\
Operation & 143 & 37 & 29 & 66 \\
Time (d) & & & &
\end{tabular}

-, Not Evaluated

\section{Synthetic wastewater composition}

The glycerol solution was adjusted in each operational phase according to the $\mathrm{C} / \mathrm{N}$ and $\mathrm{C} / \mathrm{P}$ ratio shown in Table 1. The nutrient solution was composed of macro- and micronutrients, simulating the mineral composition of a typical effluent from a secondary sewage treatment system, with nitrogen as nitrate $\left(30 \mathrm{mgNO}_{3}-\mathrm{N} . \mathrm{L}^{-1}\right)$ and phosphorus as phosphate $\left(10 \mathrm{mgPO}_{4}-\mathrm{P}^{-L^{-1}}\right)$. The macronutrients composition was as follows (in mg.L$\left.{ }^{1}\right): \mathrm{NaNO}_{3}$ (182.04); $\quad \mathrm{MgSO}_{4} \cdot 7 \mathrm{H}_{2} \mathrm{O}$ (12.55); $\mathrm{KH}_{2} \mathrm{PO}_{4}$ (43.94); $\mathrm{NaCl}$ (125), and $\mathrm{CaCl}_{2} \cdot 2 \mathrm{H}_{2} \mathrm{O}$ (4.5) and sodium bicarbonate (50). The trace mineral solution was also added to avoid processing limitations arising due to a lack of micronutrients. It was similar to that used by Touzel and Albagnac (1983) and contained (in mg. $\mathrm{L}^{-1}$ ): Nitrilotriacetic Acid (12.8); $\quad \mathrm{FeCl}_{3} \cdot 6 \mathrm{H}_{2} \mathrm{O}(1.35) ; \quad \mathrm{MnCl}_{2} \cdot 4 \mathrm{H}_{2} \mathrm{O}(0.1)$; $\mathrm{CoCl}_{2} \cdot 6 \mathrm{H}_{2} 0$ (0.024); $\mathrm{ZnCl}_{2}(0.1) ; \mathrm{CuCl}_{2} \cdot 2 \mathrm{H}_{2} 0$ (0.025); $\mathrm{H}_{3} \mathrm{BO}_{3}(0.01) ; \mathrm{Na}_{2} \mathrm{MoO}_{4} \cdot 2 \mathrm{H}_{2} 0(0.024) ; \mathrm{NiCl}_{2} \cdot 6 \mathrm{H}_{2} \mathrm{O}(0.12)$; $\mathrm{Na}_{2} \mathrm{SeO}_{3} 5 \mathrm{H}_{2} \mathrm{O}(0.026)$. The feed solution was maintained at $\mathrm{pH} 7.3 \pm 0.2$ and the alkalinity at $51.2 \pm 11.0 \mathrm{mgCaCO}_{3} \cdot \mathrm{L}^{-1}$.

\section{Analytical Methods}

The system performance was monitored by physical chemical analysis of influent and effluent samples of the reactor. The samples were collected twice or three times a week and analyzed according to the methods described in The Standard Methods for the Examination of Water and Wastewater (APHA, 2005): $\mathrm{pH}\left(4500-\mathrm{H}^{+} \mathrm{B}\right), \mathrm{COD}$ (5220-D), $\mathrm{NH}_{4}-\mathrm{N}\left(4500-\mathrm{NH}_{3}-\mathrm{C}\right), \mathrm{NO}_{3}-\mathrm{N}$ (4500- $\left.\mathrm{NO}_{3}-\mathrm{C}\right)$, $\mathrm{NO}_{2}-\mathrm{N}\left(4500-\mathrm{NO}_{2}-\mathrm{C}\right), \mathrm{PO}_{4}-\mathrm{P}(4500-\mathrm{P}-\mathrm{E})$ and Suspended Solids (2540-E). Alkalinity was measured according to Dillalo and Albertson(1961) modified by Ripley et al. (1986). The dissolved oxygen concentration was determined using a Thermo Electron Orion Oximeter (Model $810 \mathrm{~A}^{+}$).

Glycerol concentration was determined by a photoenzymatic method based on Greenhill (2003). First, a glycerol stock solution of 1.0 g. $\mathrm{L}^{-1}$ was prepared to obtain seven serial solutions in triplicate ( 0 to $\left.300 \mathrm{mg} . \mathrm{L}^{-1}\right)$. In each diluted sample $(3.5 \mathrm{~mL})$, a known volume of the enzyme solution commercial Triglycerides FS Dyasys $(1.4 \mathrm{~mL})$ was added. After 5 minutes of reaction, the value of absorbance was read in a spectrophotometer (DR 4000) at a wavelength of $500 \mathrm{~nm}$, resulting in the following calibration curve for glycerol - GOH $\left(\mathrm{mg} \cdot \mathrm{L}^{-1}\right)=($ Abs - 0.0503)/0.0011, with a $\mathrm{r}^{2}=0.991$.According to Valdez et al. (2012), the glycerol analysis using the enzymatic method is as accurate as the chromatographic method. It is also fast, has a low cost, it is easy to handle and is non-toxic.

Analysis of phase contrast optical microscopy (Microscope Olympus BX60) and molecular biology (PCR / DGGE) was also performed in order to compare the morphology of the microbial community at the end of each operational phase and to detect possible changes in it. For PCR/DGGE analysis, the DNAwas extracted as described by Griffiths et al. (2000), purified and then examined by electrophoresis on agarose gel. DGGE banding patterns were read in a UV trans-illuminator (Stratagene-Eagle Eye II). Multivariate DGGE analysis of the band profiles was performed using the BioNumerics3.5 software (Applied Maths, Belgium), which were analyzed using the Pearson correlation. The dendrogram was constructed by UPGMA (Unweighted Pair Group Method with Arithmetic Averages) method. Diversity (Shannon-Wiener - H) and Dominance (D) indices were calculated using the statistical software PAST3.09 (Hammer et al., 2001).

\section{RESULTS AND DISCUSSION}

\section{Denitrification and Organic Matter Removal}

In the first operational phase, GOH was evaluated as the sole carbon source for denitrification under anoxic condition, without intermittent aeration. For the startup with glycerol, the $\mathrm{C} / \mathrm{N}$ ratio was adopted according to Grabinska Loniewska et al. (1985), who also used glycerol as a carbon source for denitrification. They obtained $98 \%$ of $\mathrm{NO}_{3}-\mathrm{N}$ removal applying a $\mathrm{COD} / \mathrm{N}$ ratio of 3.1 , which is also a value close to the stoichiometric theoretical ratio $\left(\mathrm{COD} / \mathrm{N}=2.9, \mathrm{C} / \mathrm{N}=0.9\right.$ or $\left.2.4 \mathrm{gGOH} / \mathrm{gNO}_{3}-\mathrm{N}\right)$.

At the beginning of the operation, a partial denitrification before the bioreaction zonewas observed. This occurred 
because glycerol and nutrients solutions were mixed in the same feeding flask. Thus, there was a high nitrite content in the influent sample $\left(9.7 \pm 8.8 \mathrm{mgNO}_{2}-\mathrm{N} . \mathrm{L}^{-1}\right)$, which was not desired for the biological treatment. Then, glycerol and nutrients solutions were separated, as shown in the schematic diagram in Fig. 1. Fig. 2c shows a low efficiency of $\mathrm{NO}_{3}-\mathrm{N}$ removal at the beginning of the operation because of this problem.

After separating the solutions, denitrification efficiency was improved, but process stability was not achieved.

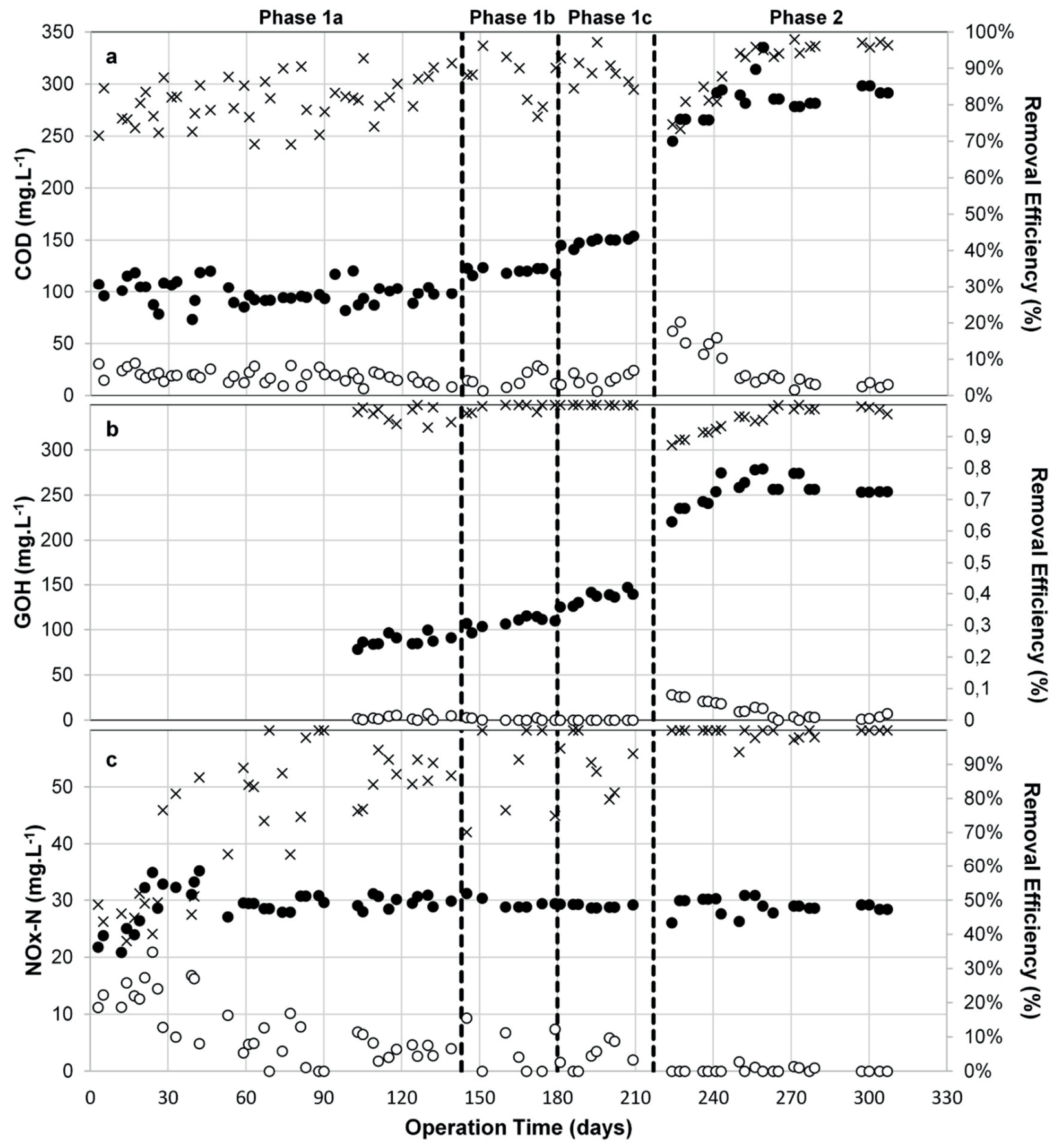

Figure 2. Temporal variation graphs of $\mathrm{COD}(\mathrm{a}), \mathrm{GOH}(\mathrm{b})$ and $\mathrm{NOx}-\mathrm{N}(\mathrm{c})$, regarding influent $(\bullet)$, effluent $(\circ)$ and removal efficiency $(\times)$ throughout the reactor operation. 
Therefore, the $\mathrm{COD} / \mathrm{N}(\mathrm{C} / \mathrm{N})$ ratio was increased in order to obtain complete and stable denitrification, resulting in two more work conditions at phase 1, as shown in Table 1. At the $\mathrm{C} / \mathrm{N}$ of 1.8 , denitrification efficiency was higher and the instability was lower.

In the second phase, the $\mathrm{C} / \mathrm{N}$ ratio was increased (3.5 \pm 0.2 ) aiming to provide the generation of VFA during the no aerated phase, thus favoring the development of BPR. However, in some cases, a high $\mathrm{C} / \mathrm{N}$ ratio can harm the denitrification performance. Her and Huang (1995) observed that, by applying a $\mathrm{C} / \mathrm{N}$ ratio from 5.0 using methanol and from 3.6 for benzoic acid, denitrification efficiency falls linearly until ceasing completely for the $\mathrm{C} / \mathrm{N}$ ratio of 10.0 and 15.0 , respectively. From the results presented (Fig. 2c), the sharp increase in the $\mathrm{C} / \mathrm{N}$ ratio led to a better performance in the denitrification and enhanced operational stability. Therefore, the denitrification with glycerol as a sole carbon source was favored by the higher $\mathrm{C} / \mathrm{N}$ ratios.

Regarding organic matter removal, as $\mathrm{COD}$ or $\mathrm{GOH}$, it can be concluded that the biomass adapted well to this carbon source, asalmost the total consumption of glycerol was obtained during the entire monitoring period $(\mathrm{GOH}$ removal of $99 \pm 2 \%$ ). With the increase of $\mathrm{C} / \mathrm{N}$ ratio in the second phase, a residual glycerol content in the effluent of the anoxic stage effluent was observed, but it was practically all consumed after the aerobic stage, as shown in Fig. 2a and 2b.

Fig. 3 shows a box-plot graph of COD and NOx-N removal efficiency for the four tested operational conditions. Applying the Tukey statistical test at a level significance $(\alpha)$ of $5 \%$ (by statistical software PAST 3.09), Phases $1 \mathrm{c}$ and 2 differ statistically from Phases $1 \mathrm{a}$ and $1 \mathrm{~b}$ and are not statistically different from each other. It is inferred, therefore, that for $\mathrm{C} / \mathrm{N}$ ratios of 1.8 to 3.5 , glycerol-driven complete denitrification may occur with a total consumption of the carbon source. There is evidence that, for lower $\mathrm{C} / \mathrm{N}$ ratios using this carbon source, denitrification is much less efficient due to the lack of electron donors. Moreover, the process showed more stability at higher $\mathrm{C} / \mathrm{N}$ ratios.

The ammonia nitrogen analysis was performed in order to evaluate the possible occurrence of dissimilatory reduction of $\mathrm{NO}_{3}^{-}-\mathrm{N}$ to $\mathrm{NH}_{4}^{+}-\mathrm{N}$. Ammonia nitrogen content was not detected in the reactor effluent, ruling out this possibility.

\section{Phosphorus Removal}

Fig. 4 shows the monitoring graphs of phosphorus and VFA during the second operational phase. It was not possible to achieve significant BPR, since the phosphorus content after the aerated and the anoxic stage was very similar (Fig. 4a), indicating that a PAO community did not develop in the reactor. There was no effective release of

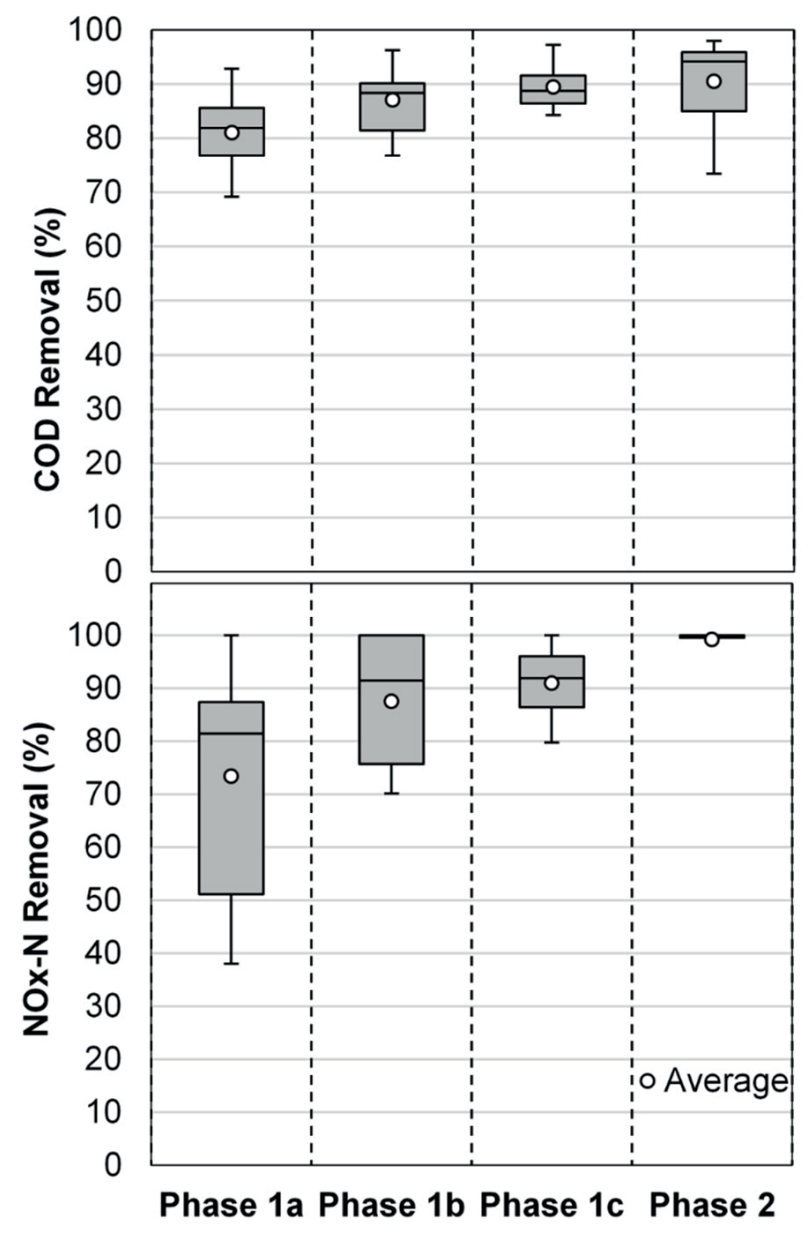

Figure 3. Box-plot graph of the distribution of COD and NOx-N removal efficiency results at each phase.

orthophosphate during the non-aerated stage, indicating that the eventual generation of short chain VFA was not enough to accumulate PHA (Fig. 4b). According to Patel and Nakhla (2006), the effective P removal selectively requires the existence of short chain fatty acids and hence the nature of the organic substance plays a key role in $\mathrm{P}$ removal.

As reported in the literature (Kuba et al., 1994; Akin and Ugurlu, 2004, Zhaoxu et al., 2010), the nitrate content might have influenced the non-occurrence of the orthophosphate release into the liquid medium. The denitrifier organisms consume a portion of the substrate before the substrate can be used by the PAO, reducing the VFA available for the PHA synthesis. The PHA storage is most efficient under anaerobic conditions where there are no competing reactions, therefore enabling complete utilization of the available VFA to form the storage polymer (ZENG, 2004).

Gerber et al. (1987) studied the role of short chain VFA and nitrate on the anaerobic treatment zone for BPR systems. They found that the release of phosphorus in the presence of nitrate occurred only for reactors with acetic, 


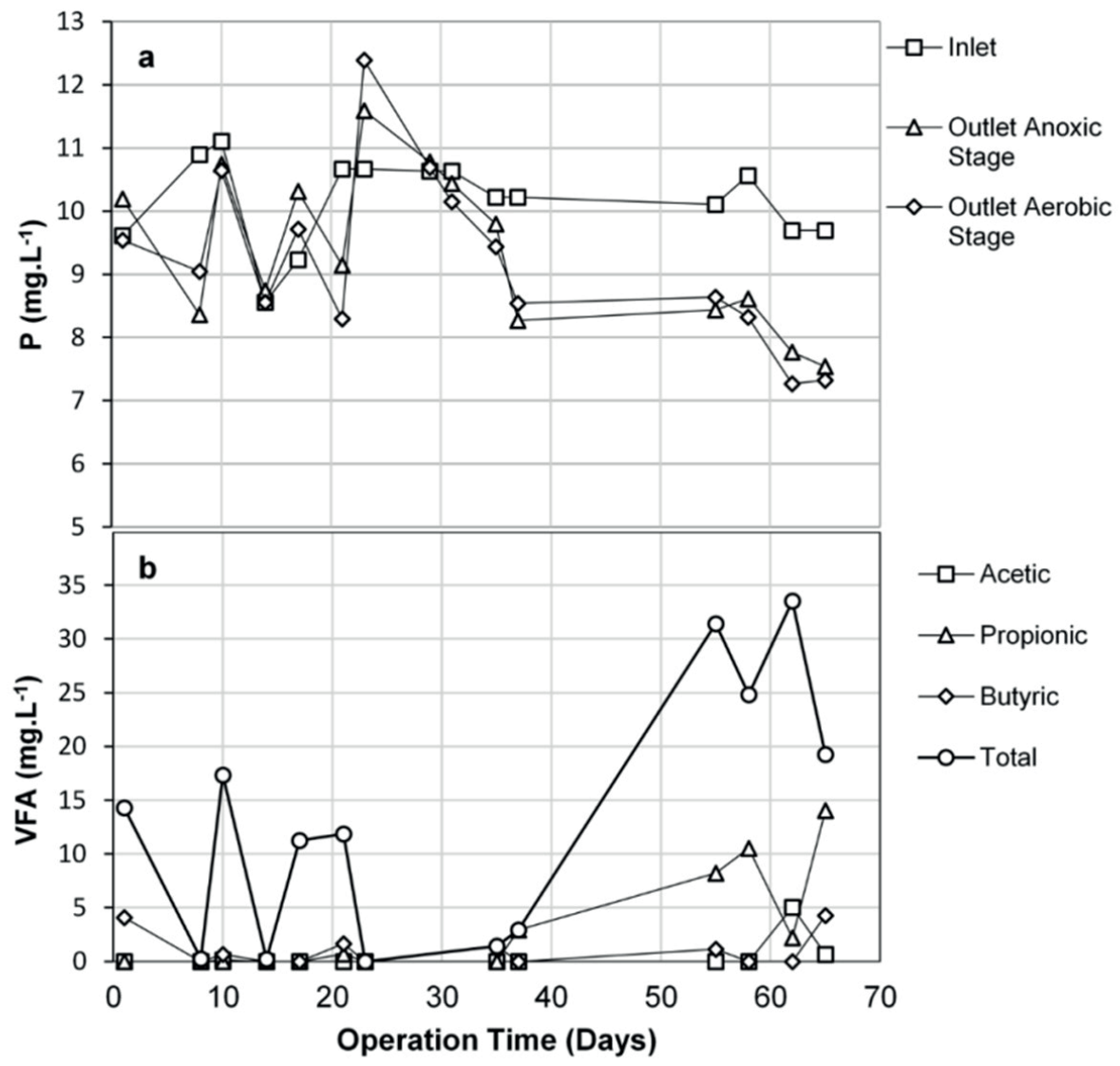

Figure 4. Temporal variation graphs of Phosphorus (a) and VFA (b) during the second operational phase.

propionic and formic acids. In the presence of glucose, ethanol, methanol and other acids such as butyric, lactic, citric and succinic acids, phosphate release does not occur until the nitrate reduces completely. This corroborates the hypothesis of the lack of short chain VFA for PAO development.

Fig. $4 \mathrm{~b}$ shows the low concentration of VFA generated in the non-aerobic stage, with an Ac/P (Acetate / Phosphorus) ratio of $0.05 \pm 0.14$. It emphasizes the idea that there was no effective glycerol fermentation during the non-aerated stage, since it was almost entirely consumed in the denitrification step. Choi et al. (2008) studied the effect of acetate during the P-removal and denitrification of wastewater and found that $7 \mathrm{mg} . \mathrm{L}^{-1}$ of acetate was consumed per $1 \mathrm{mg} . \mathrm{L}^{-1}$ of $\mathrm{P}$ removed. Cuevas-Rodríguez et al. (1998) operated a sequential batch reactor applying an $\mathrm{Ac} / \mathrm{P}$ ratio of 9.37 to remove $15 \mathrm{mgPO}_{4}-\mathrm{P} . \mathrm{L}^{-1}$. Using an Ac/P ratio of 12.8, Callado and Foresti (2001) obtained 96\% of $\mathrm{P}$ removal in a sequential batch reactor, after all the $\mathrm{NO}_{3}$ was reduced in the anoxic phase, and observed that the amount of acetate added was sufficient for denitrification and $\mathrm{P}$ release during the non-aerated stage.

Another pathway which could be used to promote biological phosphorus removal in the proposed system would be bydenitrifying phosphate accumulating organisms
(DNPAO) using nitrite or nitrate as electron acceptors for storage of Poly P (Tsuneda et al., 2006). However, it was observed that this did not occur in the system probably due to a lack ofavailableorganic substrate suitable to be used by $\mathrm{PAO}$ as acetate.

According to Artan et al. (1998), the phosphate uptake rate under anoxic conditions is lower than that underaerobic conditions. However, in the presence of an external substrate such as glucose and acetate, the fate ofphosphate was dependent on the substrate type; phosphate release occurred in the presence of nitrate as long asacetate was present and glucose did not cause any phosphate release. The nitrate uptake rate was also much lowerwith glucose than acetate. The results implied that poly-hydroxyalkanoates could be oxidized by nitrate and phosphateuptake during the anoxic phase should be introduced into process modeling.

\section{Microbiology Results}

Based on the optical microscopy, the presence of filamentous bacteria similar to the genus Beggiatoa (Fig. 5) was observed, particularly during the second operational phase due to the intermittent aeration. Beggiatoa can grow chemoorgano-heterotrophically 


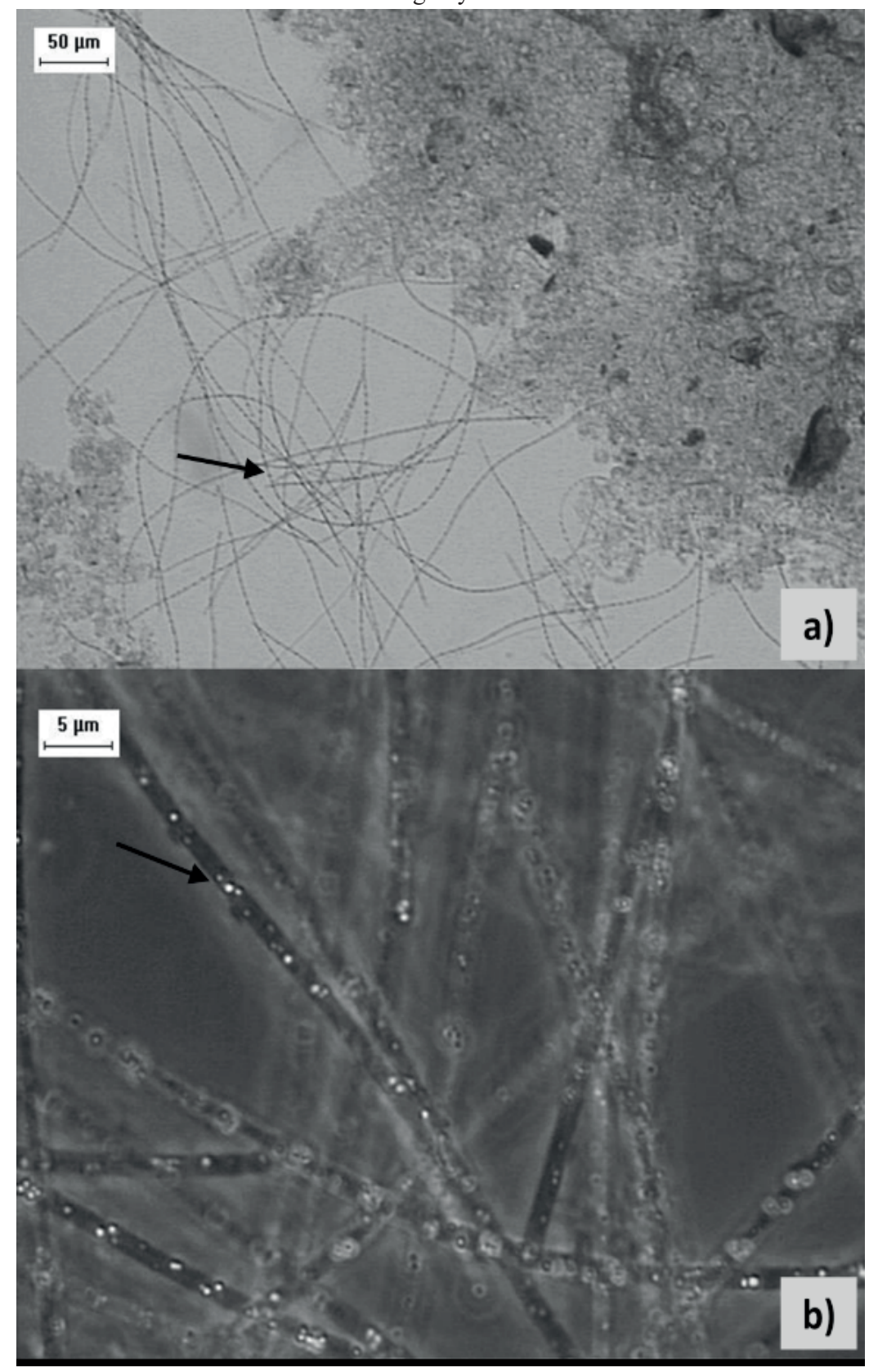

Figure 5. Optical microscopy images in a second operational phase. a) Filamentous bacteria; b) Beggiatoa highlighting the elemental sulfur granules.

from reduced sulfur compounds as electron donors and by using organic compounds as carbon sources, such as short chain fatty acids. They oxidize the reduced sulfur, storing it intracelularly as elemental sulfur granules, as shown in the microscopy image (Fig. 5b). Due to its aerobic cell metabolism, Beggiatoa needs molecular oxygen, but this bacterium is adapted to micro-aerophilic conditions. However, Kamp et al. (2006) and Sweerts et al. (1990) show that they can also use nitrate as an electron acceptor, promoting denitrification. It is supposed that these bacteria might also have contributed to the non-development of PAO, by consuming part of the short chain VFA, such as acetate or propionate.

The DGGE analysis (Fig. 6) demonstrated a high similiarity between the operational phases (90\%), indicating that the intermittent aeration did not significantly alter the microbial community. However, the results of the Shannon Diversity index $(\mathrm{H})$ and Dominance index (D) indicated a slight difference: Phase $1-\mathrm{H}=3.1, \mathrm{D}=0.052$; Phase $2-\mathrm{H}=2.9, \mathrm{D}=0.063$. Thus, it can be supposed that intermittent aeration at phase 2 might lead to greater dominance of some species, such as filamentous bacteria Beggiatoa observed in the optical microscopy assay (Fig. $5 b)$. 


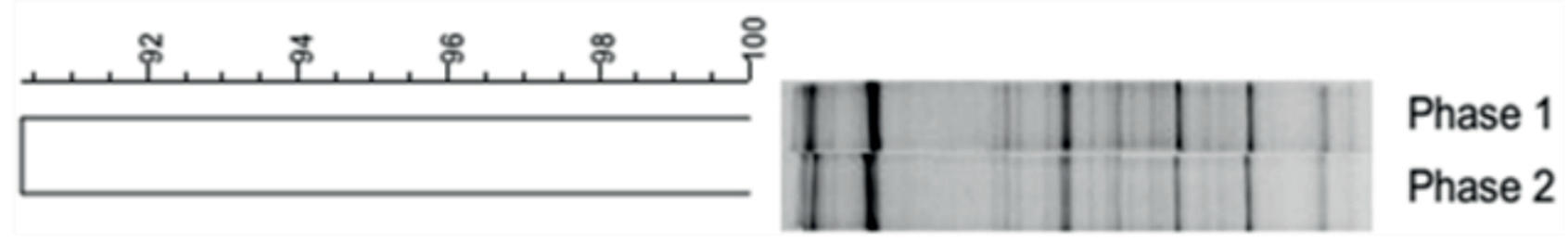

Figure 6. Similarity coefficients of the DGGE band patterns for the Bacteria domain of sludge samples at the end of each operational phase.

\section{CONCLUSIONS}

Glycerol can be applied as a sole carbon source for denitrification in an up-flow sludge bed reactor, operating with a HRT of 4 hours. For the $\mathrm{C} / \mathrm{N}$ ratios tested, the values of 1.8 and 3.5 showed complete and stable denitrification without nitrite accumulation, indicating that glyceroldriven denitrification is favoured for higher $\mathrm{C} / \mathrm{N}$ ratios.

The BPR was not achieved in the reactor with intermittent aeration applying the glycerol directly into the non-aerated stage at a C/P ratio of $10.2 \pm 1.0$, due to the low production of short chain VFA to promote orthophosphate release and subsequent accumulation in the aerobic stage by PAO. It is assumed that they did not develop because of the dominance of the heterotrophic denitrifying bacteria, which might have consumed organic substrate available for the BPR.

The presence of sulfur oxidising denitrifying bacteria, such as Beggiatoa, may also have contributed to the low Ac/P ratio, with dominance on the fermentative bacteria and consequently affecting the PAO development.

Further studies are needed to evaluate the use of fermented glycerol inthe intermittent aeration reactor, to provide a generation of short chain VFA, in order to achieve the enhanced biological phosphorus removal in the system.

\section{ACKNOWLEDGEMENTS}

The authors would like to thank FAPESP (Fundação de Amparo à Pesquisa do Estado de São Paulo, Brasil), Process $n^{\circ}$ 2009/15984-0 and CAPES (Coordenação de aperfeiçoamento de Pessoal de Nível Superior) for supporting this research.

\section{REFERENCES}

Ahmed, Z., Lim, B. R., Cho, J., Song, K. G., Kim, K. P., and Ahn, K. H. Biological nitrogen and phosphorus removal and changes in microbial community structure in a membrane bioreactor: Effect of different carbon sources. Water Research, 42(1), 198-210(2008).

Akin, B. S., Ugurlu, A. The effect of an anoxic zone on biological phosphorus removal by a sequential batch reactor. Bioresource Technology, 94(1), 1-7(2004).
ANP - Agência Nacional do Petróleo, Gás Natural e Biocombustíveis. Anuário Estatístico Brasileiro do Petróleo, Gás Natural e Biocombustiveis 2015. Río de Janeiro: ANP, 2015.

APHA, AWWA, WEF, 2005. Standard Methods for the Examination of Water and Wastewater, $21 \mathrm{st}$ ed.,Washington, DC, USA.

Artan, N., Tasli, R., Özgür, N., \& Orhon, D. The fate of phosphate under anoxic conditions in biological nutrient removal activated sludge systems. Biotechnology Letters, 20(11), 1085-1090(1998).

Asadi, A., Zinatizadeh, A. A. L., and Isa, M. H. Performance of intermittently aerated up-flow sludge bed reactor and sequencing batch reactor treating industrial estate wastewater: A comparative study.Bioresource Technology, 123, 495506(2012).

Barana, A. C., Lopes, D. D., Martins, T. H., Pozzi, E., Damianovic, M. H. R. Z., Del Nery, V., and Foresti, E. Nitrogen and organic matter removal in an intermittently aerated fixedbed reactor for post-treatment of anaerobic effluent from a slaughterhouse wastewater treatment plant.Journal of Environmental Chemical Engineering, 1(3), 453-459(2013).

Callado, N.; Foresti, E. Removal of organic carbon, nitrogen and phosphorus in sequential batch reactors integrating the aerobic/anaerobic processes. Water Science \& Technology, 44(4), 263-270(2001).

Choi, H. J., Lee, S. M., Choi, C. H., Kwon, M. C., and Lee, H. Y. Influence of the wastewater composition on denitrification and biological P-removal in the S-DN-P-process:(b) Effect of acetate.Journal of Hazardous Materials, 158(1), 151156(2008).

Cuevas-Rodríguez, G., González-Barceló, Ó., and GonzálezMartínez, S. Wastewater fermentation and nutrient removal in sequencing batch reactors. Water Science and Technology, 38(1), 255-264(1998).

DiLallo, R., Albertson, O. E., Volatile acids by direct titration. Journal (Water Pollution Control Federation), 356365(1961).

Gerber, A., De Villiers, R. H., Mostert, E. S., and Van Riet, C. J. J.The phenomenon of simultaneous phosphate uptake and release, and its importance in biological nutrient removal. Biological Phosphate Removal from Wastewaters, 123-134(1987).

Grabińska-Loniewska, A., Słomczyński, T., and Kańska, Z. Denitrification studies with glycerol as a carbon source. Water Research,19(12), 1471-1477(1985). 
Greenhill, Stacey. (2003).Method for determination of free and combined glycerin in biodiesel. U.S. Patent Application 10/744,272, 22 dez. 2003.

Griffiths, R. I., Whiteley, A. S., O'Donnell, A. G., and Bailey, M. J. Rapid method for coextraction of DNA and RNA from natural environments for analysis of ribosomal DNA-and rRNA-based microbial community composition. Applied and Environmental Microbiology, 66(12), 5488-5491(2000).

Hammer, Ø., Harper, D. A. T., and Ryan, P. D. PAST: Paleontological Statistics Software Package for education and data analysis. Palaeontologia Electronica4(1): 9pp.(2001).

Her, J. J.; Huang, J. S. Influences of carbon source and $\mathrm{C} / \mathrm{N}$ ratio on nitrate/nitrite denitrification and carbon breakthrough. Bioresource Technology, 54(1), 45-51 (1995).

Isaacs, S. H., Henze, M. Controlled carbon source addition to an alternating nitrification-denitrification wastewater treatment process including biological $\mathrm{P}$ removal. Water Research, 29(1), 77-89(1995).

Kamp, A., Stief, P., and Schulz-Vogt, H. N. Anaerobic sulfide oxidation with nitrate by a freshwater Beggiatoa enrichment culture. Applied and Environmental Microbiology, 72(7), 4755-4760(2006).

Kuba, T., Wachtmeister, A., Van Loosdrecht, M., and Heijnen, J., Effect of nitrate on phosphorus release in biological phosphorus removal systems.Water Science and Technology, 30(6), 263-269(1994).

Moura, R. B., Damianovic, M. H. R. Z., Foresti, E.,Nitrogen and carbon removal from synthetic wastewater in a vertical structured-bed reactor under intermittent aeration. Journal of Environmental Management, 98, 163-167.

Patel, J., Nakhla, G. Interaction of denitrification and P removal in anoxic P removal systems. Desalination, 201(1), 8299(2006).

Ripley, L. E., Boyle, W. C., and Converse, J. C. Improved alkalimetric monitoring for anaerobic digestion of highstrength wastes. Journal (Water Pollution Control Federation), 406-411(1986).

Santos, C. E. D., Moura, R. B., Damianovic, M. H. R. Z., Foresti, E. Influence of $\mathrm{COD} / \mathrm{N}$ ratio and carbon source on nitrogen removal in astructured-bed reactor subjected to recirculation and intermittentaeration (SBRRIA). Journal of Environmental Management, 166, 519-524(2016).

Sweerts, J. P. R., De Beer, D., Nielsen, L. P., Verdouw, H., Van den Heuvel, J. C., Cohen, Y., and Cappenberg, T. E. Denitrification by sulphur oxidizing Beggiatoa spp. mats on freshwater sediments. Nature, 344(6268), 762-763(1990).

Tam, N. F. Y., Wong, Y. S., and Leung, G. Effect of exogenous carbon sources on removal of inorganic nutrient by the nitrification-denitrification process. Water Research, 26(9), 1229-1236(1992).

Touzel, J. P., and Albagnac, G. Isolation and characterization of Methanococcus mazei strain MC3. FEMS Microbiol Lett, 16, 241-245(1983).

Tsuneda, S., Ohno, T., Soejima, K., and Hirata, A. Simultaneous nitrogen and phosphorus removal using denitrifying phosphate-accumulating organisms in a sequencing batch reactor. Biochemical Engineering Journal, 27(3), 191-196 (2006).

Valdez, H. da Cal, Amado, R. S., de Souza, F. C., D'Elia, E., and de Castro Vieira, E. Determinação de glicerol livre e total em amostras de biodiesel por método enzimático com detecção colorimétrica. Quim. Nova,35(3), 601-607(2012).

Wang, Y., Peng, Y., and Stephenson, T. Effect of influent nutrient ratios and hydraulic retention time (HRT) on simultaneous phosphorus and nitrogen removal in a two-sludge sequencing batch reactor process. Bioresource Technology, 100(14), 3506-3512(2009).

Wosiack, P. A., Lopes, D. D., Damianovic, M. H. R. Z., Foresti, E., Granato, D., and Barana, A. C. Removal of COD and nitrogen from animal food plant wastewater in an intermittentlyaerated structured-bed reactor. Journal of Environmental Management, 154, 145-150(2015).

Zeng, R. J., Yuan, Z., and Keller, J. Improved understanding of the interactions and complexities of biological nitrogen and phosphorus removal processes. Reviews in Environmental Science and Bio/Technology, 3(3), 265-272(2004)..

Zhaoxu, P. E. N. G., Yongzhen, P. E. N. G., Lijuan, G. U. I., and Xuliang, L. I. U. Competition for single carbon source between denitrification and phosphorus release in sludge under anoxic condition. Chinese Journal of Chemical Engineering, 18(3), 472-477(2010). 